\title{
Nutritional value of five rangeland plants using gas production technique
}

\author{
E. Talebi ${ }^{1,}{ }^{*}$, A.A. Salmani ${ }^{2}$, M. Yousef-Elahi ${ }^{2}$ and M.R. Dehghani2 ${ }^{2}$ \\ ${ }^{1}$ Dept. of Animal Sciences, Darab branch, Islamic Azad University, Darab, Fars, Iran \\ ${ }^{2}$ Dept. of Animal Sciences, Faculty of Agriculture, University of Zabol, Zabol, Iran
}

Corresponding authors: E. Talebi, Dept. of Animal Sciences, Darab branch, Islamic Azad University, Darab, 74817-83143, Fars, Iran. ORCiD: https://orcid.org/0000-0001-6225-2287

Mobile no: +98-917-7312823, Fax: +98-71-53560075

E-mail address: talebi226@iaudarab.ac.ir

E. Talebi*: Supervised, Designed the experiment, Guided and wrote the manuscript, Analyzed data

A.A. Salmani: Designed, Conducted the experiment

M. Yousef-Elahi: Supervision, Guided and comments on manuscript

M.R. Dehghani: Supervision and provided comments on manuscript, Analyzed data

\section{Nutritional value of five rangeland plants using gas production technique}

\begin{abstract}
This investigation was conducted to determine the chemical composition and nutritional value of five plant species commonly used as ruminant feeds namely: Artemisia herba-alba, Acer monspessulanum, Amygdalus lycoides, Amygdalus scoparia, and Atriplex leucoclada. After the collecting samples, the chemical compositions of plants included dry matter (DM), organic matter (OM), crude protein (CP), ether extract (EE), ash (CA), cell wall (NDF), and non-lignin cell wall (ADF) were determined according to standard methods. For degradation testing, the nylon bag technique was applied using three native Sistani fistula calves. Organic matter digestibility (OMD) and metabolisable energy (ME) were determined through the gas production technique. The CP value ranged from 5.30 (Amygdalus scoparia) to $11.72 \%$ (Atriplex leucoclada) while NDF value ranged from 52.62 (Amygdalus lycoides) to $69.05 \%$ (Amygdalus scoparia). The range of OMD, DOMD, and ME was from 36.67 to $53.27 \%, 34.67$ to $49.11 \%$, and 5.57 to $8.08(\mathrm{MJ} / \mathrm{kg})$, respectively. The results showed a positive correlation between cell wall composition and dry matter digestibility in plant species. The nutritional value of Amygdalus lycoides, Atriplex leucoclada, Acer monspessulanum, and Artemisia herba-alba was acceptable composition and digestibility.
\end{abstract}


Keywords: Chemical composition, Dry matter digestibility, Gas test

\section{1-Introduction}

The daily requirements of livestock depend on body weight and environmental factors (Burger, 1994; Porto et al., 2012) and pasture is a suitable source to meet the needs of livestock. Different climates have a variety of vegetations with differences in quantity and quality of forage (Lee, 2018).

Rangeland ecosystems are generally unstable and fragile biological systems that are easily affected by various factors, especially changes in rainfall and temperature (Colhoun, 1973; Izaurralde et al., 2011; Hatfield and Prueger, 2015; Yahdjian et al., 2015). In the field of natural resources, the effect of drought due to severe decrease in rainfall and increase in temperature leads to a decrease in quantity and quality of forage (Breshears et al., 2016; McCollum et al., 2017). The effects of this phenomenon are intensified when, on the one hand, it continues for several consecutive years and, on the other hand, it coincides with inappropriate and uncontrolled activities of these resources, which ultimately reduces vegetation, livestock production, and income of rangeland users (Finch et al., 2016).

Rangelands of different climatic regions have different plant composition and nutritional value (Colhoun, 1973; Mountousis et al., 2008; Keba et al., 2013; Hatfield and Prueger, 2015; Polley et al., 2017; Koutsoukis et al., 2019). Researchers stated that the highest quality was obtained in the initial stage of the growing period (Sampson, 1919; Ball et al., 2001). The low values of ash in plants were due to their vegetative stage and ash\% increased with the growth of the plant. The development of maturity, the number of leaves in the lower parts of the plant decreases then with the development of maturity, the percentage of protein decreases and the effective ash increases in the plant (Erkovan et al., 2009; Bumb et al., 2016). Atriplex leucoclada showed that this plant has 6 to 14\% crude protein (Ben Salem et al., 1994).

Currently, most of the world problems in livestock production are high production costs; low food efficiency due to insufficient food and lack of optimal use of available resources which are two important factors for proper management and maximum production. The use of rangeland plants can play an important role in reducing the cost of nutrients (Al-Masri, 2013; DiTomaso et al, 2017). 
Therefore, to obtain fodder at a reasonable price, rangeland conservation, vegetation maintenance, and proper management are very important in establishing livestock and rangeland balance (Behnke and Scoones, 1992; Critchley et al., 2004; Vickers et al., 2012). Rangeland conservation methods, plant species and animal breeds, production, physiological condition and season of the year can be effective in using rangeland (ElShaer, 2010; Fuhlendorf et al., 2012; Askar et al., 2013).

Pastures, as the widest land area of the world, also occupy a significant part of Iran. According to the latest estimates, Iran's rangeland was estimated at more than 90 million hectares about 50 years ago, but now is about 84.7 million hectares, which covers about $52 \%$ of the country's area. The $8.5 \%, 25.3 \%$, and $66.2 \%$ are dense rangelands, semi-dense rangelands, and low-density rangelands, respectively. This vast area is considered as one of the basic sources of production in the country and has a special place in providing fodder needed by livestock. About 10.7 million tons of fodder is produced annually under normal rainfall in the country's rangelands (ISNA, 2018).

The method of in vitro digestion and gas production for determining digestibly and metabolisable energy is quickly expanding because of an increased need for routine and reproducible methods to gather data on bioavailability of feeds in addition to the chemical composition (Blu and Ørskov, 1993). Awareness of the nutrients in forage that are available to grazing animals will be an effective aid in their timely use, predicting nutrient deficiencies as well as assessing nutritional supplement needs. The amount of unstructured carbohydrate reserves in the plant is a good indicator of changes in stress in the plant and is a useful measure for estimating the digestibility of forage consumed by livestock (McDonald et al., 1996; Arzani et al., 2004). Then, determining the nutritional value of plant species, calculating livestock units and proper rangeland management, in addition to reducing the cost of livestock products, can prevent overgrazing and destruction of rangelands. The aim of this study was to determine the nutritional value of five species of rangeland plants for consumption in animal nutrition in order to provide part of the nutritional needs of livestock in the region.

\section{2-Materials and Methods}

\subsection{Description of sampling site}


Darab plain was located in the southeast of Fars province and in the range of $54^{\circ} 11^{\prime}$ to $54^{\circ} 47^{\prime} \mathrm{E}$ and $28^{\circ} 33^{\prime}$ to $28^{\circ} 49^{\prime} \mathrm{N}$ at a distance of $250 \mathrm{~km}$ from Shiraz. The climate of the region based on the Köppen classification was very hot dry climate. According to Zahak meteorological station, the long-term average rainfall was $63 \mathrm{~mm}$ with the annual evaporation rate of 5000-4500 $\mathrm{mm}$.

\subsection{Livestock maintenance}

For degradation testing, three native Sistani male calves with a fistula installed in the rumen were used. Calves' diets were adjusted to the maintenance level (NRC, 2001) using dried alfalfa, wheat straw, and concentrate. The amount of energy and protein was $1.2 \mathrm{MJ} / \mathrm{kg}$ and $14 \%$. The feed was fed in two meals at 8:00 am and 17:00 pm and the water was supplied ad libitum to the animals.

\subsection{Sampling of species}

Five species of rangeland plants including Amygdalus lycoides, Amygdalus scoparia, Atriplex leucoclada, Artemisia herba-alba and Acer monspessulanum were used. All experiments were performed in Animal Nutrition Laboratory, Department of Animal Sciences, Agriculture Laboratory, Agriculture and research farm located in Sistan, Iran.

\subsection{Experiment 1}

This experiment was performed to determine the chemical composition and nutritional value of five tropical rangeland plants. Sampling of aerial parts of plant species (a few centimeters above the ground) by completely random method and harvesting three replicates per each at an average of 500 grams in the pastures of Rustaq and Fedami areas were collected in April. The species after harvesting and mixing replicates of each species separately were exposed to open air and shade for 72 hours. After drying, plant samples were ground with a sieve mill (diameter of $2 \mathrm{~mm}$ ).

\subsubsection{Chemical composition}

Dry matter (DM) using an oven at $60{ }^{\circ} \mathrm{C}$ for 48 hours, crude fat (EE) through organic solvent extraction method (Soxhlet apparatus), ash (CA) by AOAC, crude protein (CP) by Kjeldal method, organic matter $(\mathrm{OM})$ by computational method, insoluble fibers in neutral detergent (NDF) and insoluble fibers in acid detergent (ADF) was measured using the method of Van Soust (1990). Neutral 
detergent solution (NDS) and fiber bag device were used to measure NDF and acid detergent solution (ADS) and fiber bag device were used to measure ADF.

\subsection{Experiment 2}

\subsubsection{Dry matter degradability method (in situ)}

In this study, three Sistani male calves with an average weight of $380 \pm 12.5 \mathrm{~kg}$ and 36 months of age with a fistula installed in their rumen were used for degradability testing (Ørskov Ørskov and McDonald, 1979). The value of $5 \mathrm{~g}$ of dried and ground sample from each plant (with a diameter of $2.5 \mathrm{~mm}$ ) was prepared inside polyester bags with dimensions of $8 \times 15 \mathrm{~cm}$ and pore diameter of $50 \mu \mathrm{m}$. Then bags containing the sample for 6, 12, 24, 36, 45, 72 and 96 hours (14 bags each time 3 repetitions per treatment) were placed in the calves' rumen and after the end of each of the desired times, out of the rumen and rinsed with cold water and dried in an oven at $65^{\circ} \mathrm{C}$ for 48 hours. From the difference between the original sample and the remaining sample in the bag, the decomposed or disappearance part was calculated.

Degradability parameters [soluble fraction of coefficient (a), non-soluble fraction of coefficient (b) and constant rate of decomposition of coefficient (C)] were determined using the NLIN procedure through the SAS, 2007 and based on the exponential equation (Ørskov and McDonald, 1979). In this equation, the percentage of degradability in time $(\mathrm{t})$ was $(\mathrm{P})$. The fast section was degradable and soluble (a) and (b) was the insoluble section, which was degradable, and (C) was the rate of degradability (percentage per hour). Effective degradability (ED) at the levels of 2, 5 and $8 \%$ per hour was also calculated.

$$
\mathrm{P}=\mathrm{a}+\mathrm{b}\left(1-\mathrm{e}^{-\mathrm{ct}}\right)
$$

The effective rumen degradability (ED) of forage compounds was calculated as follow:

$$
\mathrm{ED}=\mathrm{a}+[(\mathrm{b} \times \mathrm{c}) /(\mathrm{c}+\mathrm{k})]
$$

$\mathrm{k}=$ is the amount of ruminal material flow.

2.5.2. Gas production test 
The volume of gas produced from the fermentation of the samples was determined according to Menke et al. (1979) method. To test for gas production in the incubator, ruminal fluid was taken from 3 fistulated Sistani male calves before feeding in the morning and transferred to the laboratory in a flask containing carbon dioxide and smoothed with a 4-layer cleaning cloth. Samples were milled using a $1 \mathrm{~mm}$ sieve. The $210 \pm 0.5 \mathrm{mg}$ ( 3 replicates) was poured into each syringe and $30 \mathrm{ml}$ of purified ruminal fluid mixture containing buffer (2: 1 ratio) was added to syringes (Makker, 2004). Solutions for gas production test were prepared according to Table 1. The volume of gas produced was read at $2,6,8,12,24,48,72$, and 96 hours. This test was repeated in 2 days.

Table 1 Amounts of chemicals to prepare the reagents for the gas production test

\begin{tabular}{|c|c|c|}
\hline Solution & Chemical materials & $\begin{array}{c}\text { Weight } \\
\text { (g) }\end{array}$ \\
\hline \multirow{3}{*}{ Macro mineral } & Sodium hydrogen phosphate $\left(\mathrm{Na}_{2} \mathrm{HPO}_{4}\right)$ & 5.7 \\
\hline & Potassium dihydrogen phosphate $\left(\mathrm{KH}_{2} \mathrm{PO}_{4}\right)$ & 6.2 \\
\hline & Magnesium sulfate $\left(\mathrm{MgSO}_{4}, 7 \mathrm{H} 2 \mathrm{O}\right)$ & 0.6 \\
\hline \multirow{4}{*}{ Micro mineral } & Calcium chloride $\left(\mathrm{CaCl}_{2} .2 \mathrm{H} 2 \mathrm{O}\right)$ & 13.2 \\
\hline & Manganese chloride $\left(\mathrm{MnCl}_{2} .4 \mathrm{H} 2 \mathrm{O}\right)$ & 10 \\
\hline & Cobalt chloride $\left(\mathrm{CoCl}_{2} .6 \mathrm{H}_{2} \mathrm{O}\right)$ & 1 \\
\hline & Iron chloride $\left(\mathrm{FeCl}_{3} .6 \mathrm{H}_{2} \mathrm{O}\right)$ & 0.8 \\
\hline \multirow{2}{*}{ Buffer solution } & Sodium hydrogen carbonate (NaHCO3) & 70 \\
\hline & Ammonium hydrogen carbonate $\mathrm{HCO} 3$ (NH4) & 4 \\
\hline Resazurin solution & \multicolumn{2}{|c|}{$\begin{array}{l}100 \mathrm{mg} \text { of Resazurin, which was increased to } 100 \mathrm{ml} \text { by } \\
\text { adding, distilled water. }\end{array}$} \\
\hline
\end{tabular}

\subsection{Calculations}

For measuring OMD, the volume of gas produced based on $200 \mathrm{mg}$ of DM during 24 hours and the following equation were used (Menke et al., 1979):

\section{$\mathrm{OMD}=14.88+0.8893 \mathrm{GP}+0.0448 \mathrm{CP}+0.0651 \mathrm{ASH}$}

OM: Digestibility of organic matter (g/kg DM)

GP: Corrected gas volume for 24 hours (ml/200 mg of DM).

$\mathrm{CP}$ : crude protein $(\mathrm{g} / \mathrm{kg} \mathrm{DM})$

ASH: Crude ash (g/kg DM) 
Digestible organic matter (DOMD) was obtained through below equation:

$$
\mathrm{DOMD}=\mathrm{OMD} \times \% \mathrm{OM}
$$

DOMD: Digestible Organic Matter in Dry Matter (\%)

OMD: Organic matter digestibility (\%)

OM: Sample Organic Matter (\%)

Also, estimation of ME was calculated based on the following equation (Menke et al., 1979):

\section{$\mathrm{ME}=2.2+0.1357 \mathrm{GP}+0.0057 \mathrm{CP}+0.00002859 \mathrm{CP}^{2}$}

ME: Metabolisable energy (MJ/kilogram of DM)

GP: Volume of gas produced (ml/200mg DM in 24h)

CP: Crude protein $(\mathrm{g} / \mathrm{kg} \mathrm{DM})$

\subsection{Statistical analysis}

The data of chemical composition was analyzed in a completely randomized design (CRD) using SAS 9.1 and mean values were compared by Duncan's multiple range through the below statistical model:

$$
Y_{i j}=\mu+X_{i}+e_{i j}
$$

$Y_{i j}$ : The numerical value of each observation, $\mu$ is the average of the total population, $X_{i}$ : the effect of the treatment, and $\mathrm{e}_{\mathrm{ij}}$ : the experimental error.

The data of in situ test and gas production were computed using Neway software and Proc NLIN program (Nonlinear regression), respectively.

\section{Results}

\subsection{Chemical composition}

The chemical compositions of the plant species are shown in Table 2. The DM and OM values ranged from 94.73 to $96.80 \%$ and 83.52 to $94.51 \%$, respectively. Other chemical compounds presented different variation, which was not unexpected due to the genetic of species and other affecting factors on plant growth.

Table 2 The average chemical composition and minerals of the plants

\begin{tabular}{llllllll}
\hline Chemical & Amygdalus & Acer & Amygdalus & Artemisia & Atriplex & SEM & P- \\
\hline
\end{tabular}




\begin{tabular}{|c|c|c|c|c|c|c|c|}
\hline composition & lycoides & monspessulanum & scoparia & $\begin{array}{c}\text { herba- } \\
\text { alba }\end{array}$ & leucoclada & & value \\
\hline $\mathrm{DM}$ & $96.70^{a}$ & $94.73^{b}$ & $96.56^{a}$ & $96.80^{a}$ & $96.76^{a}$ & 0.783 & 0.038 \\
\hline $\mathrm{OM}$ & $92.20^{\mathrm{a}}$ & $94.26^{\mathrm{a}}$ & $94.51^{\mathrm{a}}$ & $93.41^{\mathrm{a}}$ & $83.52^{b}$ & 1.511 & 0.0001 \\
\hline $\mathrm{ASH}$ & $7.80^{\mathrm{b}}$ & $5.73^{b}$ & $5.48^{b}$ & $6.59^{b}$ & $16.48^{a}$ & 1.511 & 0.0001 \\
\hline $\mathrm{CP}$ & $8.13^{b}$ & $7.47 \mathrm{c}$ & $5.30^{\mathrm{d}}$ & $7.36^{c}$ & $11.72^{\mathrm{a}}$ & 0.275 & 0.0001 \\
\hline $\mathrm{EE}$ & $5.10^{b}$ & $4.50^{\mathrm{b}}$ & $5.46^{b}$ & $7.81^{a}$ & $6.01^{b}$ & 0.893 & 0.009 \\
\hline $\mathrm{ADF}$ & $38.66^{c}$ & $43.62^{b}$ & $52.55^{\mathrm{a}}$ & $44.50^{\mathrm{a}}$ & $43.11^{b}$ & 1.780 & 0.0001 \\
\hline NDF & $52.62^{\mathrm{d}}$ & $56.39 \mathrm{c}$ & $69.05^{a}$ & $59.05^{b}$ & $53.97 \mathrm{~cd}$ & 1.444 & 0.0001 \\
\hline $\mathrm{Ca}$ & $0.2115^{b}$ & $0.1924^{c}$ & $0.1454^{\mathrm{d}}$ & $0.0896^{\mathrm{e}}$ & $0.2749^{a}$ & 0.220 & 0.0001 \\
\hline $\mathrm{P}$ & $0.07 \mathrm{c}$ & $0.086^{\mathrm{bc}}$ & $0.08^{\mathrm{bc}}$ & $0.10^{\mathrm{b}}$ & $0.15^{\mathrm{a}}$ & 0.013 & 0.0002 \\
\hline $\mathrm{Mg}$ & $0.097^{b}$ & $0.090^{\mathrm{b}}$ & $0.093^{\mathrm{b}}$ & $0.090^{\mathrm{b}}$ & $0.12^{\mathrm{a}}$ & 0.0032 & 0.0001 \\
\hline
\end{tabular}

${ }^{*}$ Numbers with dissimilar letters in each row have a statistically significant difference $(\mathrm{P}<0.05)$,

SEM: Standard error mean, DM: dry matter, OM: organic matter, ASH: ash, CP: crude protein, EE: crude fat, ADF: cell wall without hemicellulose, NDF: cell wall, Ca: calcium, P: phosphorus, Mg: magnesium

Factors affecting the DM and OM digestibility and metabolisable energy are the value of NDF and ADF in plants. Due to the significant difference between these two compounds among the studied plants, the most inappropriate quantity was recorded in Amygdalus scoparia (69.05 and 52.55\%, respectively) $(\mathrm{p}<0.05)$ and Amygdalus lycoides showed acceptable values.

\subsection{In vitro gas test}

\subsubsection{Fermentation parameters}

Average volume of gas produced at different incubation times displayed in Table 3. This factor after 24 hours of incubation ranged from 23.72 (Amygdalus scoparia) to $41.52 \mathrm{ml}$ (Amygdalus lycoides) and after 96 hours was recorded 38.66 (Amygdalus scoparia) to $54.83 \mathrm{ml}$ (Amygdalus lycoides). It is clearly that with increasing incubation time, the amount of gas produced also raised, accumulatively. According to the results, from 12 to 96 hours after incubation, the volume of gas produced by the tested plants followed the same pattern.

Table 3 Average volume of gas produced (ml/200 $\mathrm{mg}$ of DM) of the plants at different incubation times

\begin{tabular}{|c|c|c|c|c|c|c|c|}
\hline $\begin{array}{l}\text { Incubation } \\
\text { time }\end{array}$ & $\begin{array}{c}\text { Amygdalus } \\
\text { lycoides }\end{array}$ & $\begin{array}{c}\text { Acer } \\
\text { monspessulanum }\end{array}$ & $\begin{array}{c}\text { Amygdalus } \\
\text { scoparia }\end{array}$ & $\begin{array}{c}\text { Artemisia } \\
\text { herba- } \\
\text { alba }\end{array}$ & $\begin{array}{c}\text { Atriplex } \\
\text { leucoclada }\end{array}$ & SEM & $\begin{array}{l}P \text { - } \\
\text { value }\end{array}$ \\
\hline 2 & $6.17^{b}$ & $7.17 \mathrm{a}$ & $4.83^{c}$ & $6.17 \mathrm{~b}$ & $7.17 \mathrm{a}$ & 0.3415 & 0.0001 \\
\hline 4 & $12.5^{b}$ & $11.69^{a}$ & $8.58^{c}$ & $10.87^{b}$ & $13.22^{\mathrm{a}}$ & 0.4281 & 0.0001 \\
\hline 6 & $19.07^{a}$ & $16.13^{b}$ & $11.98^{c}$ & $15.34^{\mathrm{b}}$ & $19.65^{a}$ & 0.7839 & 0.0001 \\
\hline 8 & $22.76^{a}$ & $18.77^{b}$ & $13.93^{c}$ & $18.06^{\mathrm{b}}$ & $22.74^{a}$ & 1.0770 & 0.0001 \\
\hline 12 & $30.13^{a}$ & $23.55^{c}$ & $17.17^{\mathrm{d}}$ & $23.34^{c}$ & $27.78^{\mathrm{b}}$ & 1.1623 & 0.0001 \\
\hline 24 & $41.52^{\mathrm{a}}$ & $30.63^{c}$ & $23.72^{\mathrm{d}}$ & $28.46^{c}$ & $37.04^{b}$ & 1.4907 & 0.0001 \\
\hline 48 & $49.06^{a}$ & $37.22^{c}$ & $31.50^{d}$ & $32.50^{d}$ & $41.43^{b}$ & 1.5670 & 0.0001 \\
\hline 72 & $52.42^{\mathrm{a}}$ & $41.73^{\mathrm{b}}$ & $34.22^{\mathrm{b}}$ & $40.22^{c}$ & $44.05^{\mathrm{b}}$ & 1.6840 & 0.0001 \\
\hline
\end{tabular}




\begin{tabular}{llllllll}
\hline 96 & $54.83^{\mathrm{a}}$ & $46.67^{\mathrm{b}}$ & $38.66^{\mathrm{b}}$ & $45.34 \mathrm{~d}$ & $48.02^{\mathrm{bc}}$ & 1.7223 & 0.0001 \\
\hline
\end{tabular}

${ }^{*}$ Numbers with dissimilar letters in each row have a statistically significant difference $(\mathrm{P}<0.05), \mathrm{SEM}$ : Mean standard error

\subsubsection{Gas production parameter}

There was a significant difference between plants in the component of section (b) and (c) $(p<0.05)$. In Table 4, the section (b) was ranged from 33.84 (Artemisia herba-alba) to 53.01 (Amygdalus lycoides) $(\mathrm{P}<0.05)$. The value of $(\mathrm{c})$ (decomposition constant rate), which indicated the instantaneous decomposition rate of section (b), showed a significant difference between the experimental plants $(\mathrm{p}<0.05$ ). The OMD ranged from 36.67 (Amygdalus scoparia) to 53.27\% (Amygdalus lycoides) and by comparing OMD and DOMD values, it was observed that DOMD trend followed from OMD and caused a change in a ratio. Values OMD and DOMD were influenced by both sections (b) and (c), so that Amygdalus scoparia due to having a higher value of (b), and the lowest of sections (c), showed less OMD and DOMD which this may be due to chemical compounds and cell walls. ME was determined between 5.57 and $8.08 \mathrm{MJ} / \mathrm{kg}$.

Table 4 Gas production parameters of the plants

\begin{tabular}{lllccccc}
\hline Treatment & $\begin{array}{c}\text { Amygdalus } \\
\text { lycoides }\end{array}$ & $\begin{array}{c}\text { Acer } \\
\text { monspessulanum }\end{array}$ & $\begin{array}{c}\text { Amygdalus } \\
\text { scoparia }\end{array}$ & $\begin{array}{c}\text { Artemisia } \\
\text { herba }- \\
\text { alba }\end{array}$ & $\begin{array}{c}\text { Atriplex } \\
\text { leucoclada }\end{array}$ & $\begin{array}{c}\text { SEM } \\
\text { P- }\end{array}$ & $\begin{array}{c}\text { P- } \\
\text { value }\end{array}$ \\
\hline $\mathrm{b}$ & $53.01^{\mathrm{a}}$ & $40.77^{\mathrm{b}}$ & $52.76^{\mathrm{a}}$ & $33.84^{\mathrm{c}}$ & $43.14^{\mathrm{b}}$ & 1.6844 & 0.0001 \\
$\mathrm{c}$ & $0.066^{\mathrm{a}}$ & $0.058^{\mathrm{c}}$ & $0.020^{\mathrm{d}}$ & $0.087^{\mathrm{a}}$ & $0.086^{\mathrm{a}}$ & 0.0038 & 0.0001 \\
OMD & $53.27^{\mathrm{a}}$ & $42.54^{\mathrm{c}}$ & $36.67^{\mathrm{d}}$ & $41.27^{\mathrm{c}}$ & $48.68^{\mathrm{b}}$ & 1.3290 & 0.0001 \\
DOMD & $49.11^{\mathrm{a}}$ & $40.02^{\mathrm{b}}$ & $34.67^{\mathrm{c}}$ & $38.55^{\mathrm{b}}$ & $40.66^{\mathrm{b}}$ & 1.2480 & 0.0001 \\
ME & $8.08^{\mathrm{a}}$ & $6.44^{\mathrm{c}}$ & $5.57^{\mathrm{d}}$ & $6.26^{\mathrm{c}}$ & $7.42^{\mathrm{b}}$ & 0.2020 & 0.0001 \\
\hline
\end{tabular}

${ }^{*}$ Numbers with dissimilar letters in each row have a statistically significant difference $(\mathrm{P}<0.05)$, SEM: standard error of the means, OMD: digestibility of organic matter, DOMD: digestibility of organic matter in DM, ME: metabolisable energy $(\mathrm{MJ} / \mathrm{Kg})$, b: total volume of gas produced $(\mathrm{ml}) \mathrm{c}$ : constant rate of gas production

\subsubsection{Degradability parameters}

The results of dry matter degradability at various incubation times were shown in Table 5 . It is quite clear that the disappearance of DM from the nylon bags incubated in the rumen rose with increasing incubation time. Throughout the period, Amygdalus lycoides and Amygdalus scoparia manifested the highest and lowest dry matter disappearance, respectively. The results explicated that there was a 
positive correlation between the cell wall composition and the dry matter digestibility. Amygdalus lycoides had the lowest ADF and NDF; therefore, it recorded the highest digestibility among experimental plants.

Table 5 Mean dry matter degradability (\%) of the plants at different incubation times

\begin{tabular}{|c|c|c|c|c|c|c|c|}
\hline $\begin{array}{l}\text { Incubation } \\
\text { time }\end{array}$ & $\begin{array}{c}\text { Amygdalus } \\
\text { lycoides }\end{array}$ & $\begin{array}{c}\text { Acer } \\
\text { monspessulanum }\end{array}$ & $\begin{array}{c}\text { Amygdalus } \\
\text { scoparia }\end{array}$ & $\begin{array}{c}\text { Artemisia } \\
\text { herba - } \\
\text { alba }\end{array}$ & $\begin{array}{c}\text { Atriplex } \\
\text { leucoclada }\end{array}$ & SEM & $\begin{array}{l}\text { P- } \\
\text { value }\end{array}$ \\
\hline 3 & $25.31^{a}$ & $22.03^{b}$ & $16.26^{c}$ & $18.31^{b}$ & $24.07^{b}$ & 1.548 & 0.0001 \\
\hline 6 & $32.94^{\mathrm{a}}$ & $25.38^{\mathrm{b}}$ & $22.21^{\mathrm{d}}$ & $22.76^{c}$ & $28.74^{b}$ & 1.339 & 0.0001 \\
\hline 12 & $37.40^{\mathrm{a}}$ & $30.35^{b}$ & $26.69^{d}$ & $28.69^{c}$ & $31.82^{b}$ & 1.037 & 0.0001 \\
\hline 24 & $44.70^{\mathrm{a}}$ & $35.95^{\mathrm{b}}$ & $31.81^{\mathrm{d}}$ & $33.77^{c}$ & $38.59^{b}$ & 1.142 & 0.0001 \\
\hline 48 & $50.57^{a}$ & $39.45^{b}$ & $35.48^{\mathrm{d}}$ & $37.94^{\mathrm{c}}$ & $42.12^{b}$ & 1.574 & 0.0001 \\
\hline 72 & $55.33^{a}$ & $44.70^{\mathrm{b}}$ & $38.65^{d}$ & $40.65^{c}$ & $47.36^{b}$ & 1.465 & 0.0001 \\
\hline 96 & $61.43^{\mathrm{a}}$ & $47.46^{\mathrm{b}}$ & $42.36^{\mathrm{d}}$ & $45.16^{c}$ & $53.36^{\mathrm{b}}$ & 1.020 & 0.0001 \\
\hline
\end{tabular}

${ }^{*}$ Numbers with dissimilar letters in each row have a statistically significant difference $(\mathrm{P}<0.05)$, SEM: standard error of the means

According to Table 6, Amygdalus lycoides had the highest value, and also Amygdalus scoparia noted the lowest values of fast decomposition section (a) and decomposition rate constant (c). On the other hand, the potential degradability coefficients $(\mathrm{a}+\mathrm{b})$ ranged from 58.48 (Acer monspessulanum) to $68.16 \%$ (Amygdalus scoparia). The mean percentage of effective degradability (ED) of DM at the passage rate of $0.02,0.05$, and 0.08 was significantly different between plants $(\mathrm{P}<0.05)$. With reference to (a) and (c), the most acceptable percentage of effective degradability was recorded from Amygdalus lycoides, and the unsuitable was recognized in Amygdalus scoparia. With increasing incubation time, the amount of gas produced $(\mathrm{ml} / 200 \mathrm{mg}$ of $\mathrm{DM})$ increased and the most of the gas was obtained after half of the whole period (48 hours). According to the nonlinear regression equation ( $\mathrm{R}^{2}$ close to 1$)$, it was found that the amount of gas followed the logarithmic function (Fig. 1). 


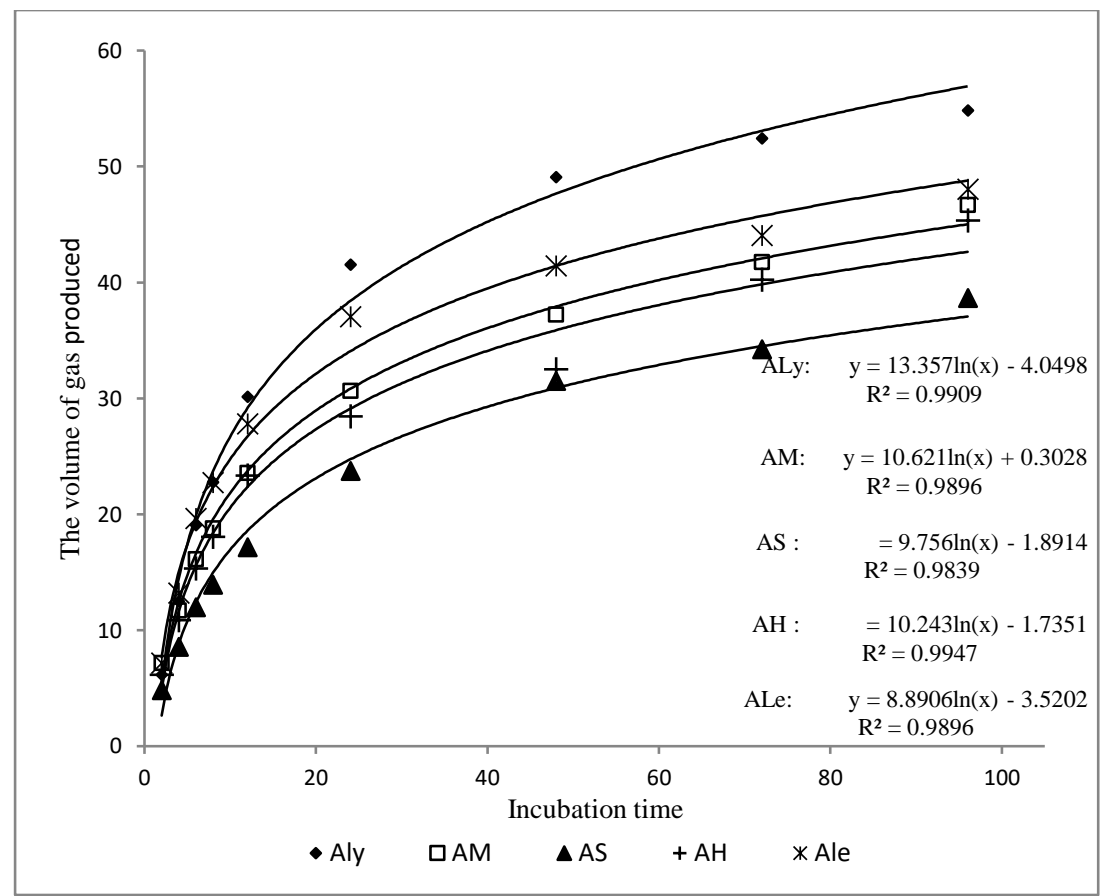

Figure 1. Logarithmic nonlinear regressionof gas produced at different incubation times (h) ALy: Amygdalus lycoides, AM: Acer monspessulanum, AS: Amygdalus scoparia, AH: Artemisia herb-alba, ALe: Atriplex leucoclada

Table 6 Percentage of degradability parameters of the plants

\begin{tabular}{|c|c|c|c|c|c|c|c|}
\hline Treatment & $\begin{array}{c}\text { Amygdalus } \\
\text { lycoides }\end{array}$ & $\begin{array}{c}\text { Acer } \\
\text { monspessulanum }\end{array}$ & $\begin{array}{c}\text { Amygdalus } \\
\text { scoparia }\end{array}$ & $\begin{array}{c}\text { Artemisia } \\
\text { herba - } \\
\text { alba }\end{array}$ & $\begin{array}{c}\text { Atriplex } \\
\text { leucoclada }\end{array}$ & SEM & $\begin{array}{l}P \text { - } \\
\text { value }\end{array}$ \\
\hline $\mathrm{a}$ & $25.28^{a}$ & $23.67^{a}$ & $17.20^{c}$ & $20.97^{b}$ & $24.93^{a}$ & 0.9073 & 0.0001 \\
\hline $\mathrm{b}$ & $39.54^{c}$ & $34.86^{\mathrm{d}}$ & $50.95^{a}$ & $39.83^{b}$ & $51.10^{\mathrm{b}}$ & 0.7964 & 0.0001 \\
\hline c & $0.0348^{\mathrm{a}}$ & $0.0107 \mathrm{~b}$ & $0.0051^{\mathrm{d}}$ & $0.0067 \mathrm{c}$ & $0.0077 \mathrm{c}$ & 0.0011 & 0.0001 \\
\hline$a+b$ & $64.82^{\mathrm{b}}$ & $58.48^{d}$ & $68.16^{a}$ & $61.02^{c}$ & $66.04^{\mathrm{b}}$ & 0.6801 & 0.0001 \\
\hline 0.02 & $50.40^{a}$ & $35.76^{c}$ & $27.60^{\mathrm{e}}$ & $31.06^{\mathrm{d}}$ & $36.33^{b}$ & 0.2863 & 0.0001 \\
\hline 0.05 & $41.50^{\mathrm{a}}$ & $29.80^{b}$ & $21.90^{\mathrm{d}}$ & $25.70^{c}$ & $30.40^{\mathrm{b}}$ & 0.3898 & 0.0001 \\
\hline 0.08 & $37.16^{\mathrm{a}}$ & $27.73^{b}$ & $20.30 \mathrm{~d}$ & $24.06^{c}$ & $28.53^{\mathrm{b}}$ & 0.4864 & 0.0001 \\
\hline
\end{tabular}

\section{Discussion}

Genotypic variation between species, growth stage and the effect of environmental factors will undoubtedly changed in the chemical composition of plants (Izaurralde et al., 2011; Dumont et al., 2014; Bhattarai et al., 2020; Gusmão Filho et al., 2020). Researcher declared that genetic diversity in rangeland plants caused significant differences in chemical composition and digestibility. In addition, maturity time, leaf to stem ratio, growth rate and plant resistance to stress could be other factors 
influencing the chemical composition of forage (Milford and Haydock, 1965; Hunt and Hay, 1990; Stewart, 1996; Melesse et al., 2012; Kfoury et al., 2019; Sgarbossa et al., 2019). The scientific reports also showed that the differences in the chemical composition of different species were related to their inherent ability to take nutrients from the soil and convert into plant tissues (Khalil et al., 1986; Towhidi et al., 2007).

In this experiment, the volume of gas produced had a negative correlation with values of NDF and ADF, which the results were in harmony with prior studies. Increasing gas production has positive correlation with dry matter digestibility and negative correlation with NDF and ADF contents; this indicated that gas production was an integral part of feed fermentation (Sommart et al., 2000; Mokhtarpour et al., 2012; Kumar et al., 2013; Kulivand and Kafilzadeh, 2015).

The highest rate of effective degradability (ED) was reported in Amygdalus lycoides with the highest coefficient of slow decomposition section (a) and decomposition rate constant (c) and the lowest rate was allocated to Amygdalus scoparia due to the low coefficient of (a) and (c). The outcomes of this research revealed a positive correlation between ED and coefficients of (a) and (c). Researchers reported that red berry leaves and white berry leaves showed the different degradability coefficient of insoluble part (b) in the rumen, which can be due to the amount of crude protein led to promote the growth of microorganisms and greater protein degradability (Ahmadi et al., 2002; Kandylisa et al., 2009; Ferlemi and Lamari, 2016; Biel and Jaroszewska, 2017). An extra factor affecting the quantity of ED is the growth stage of the plant. Bald et al. (1993) showed that effective degradability of alfalfa (DM) at different stages of growth ranged from 61.9 to $72.9 \%$. Blu and Ørskov (1993) estimated that the dry matter digestibility of alfalfa was 0.93 through a multiple regression model. The disappearance of dry matter in the leaves within 48 hours of incubation was equivalent to degradability (Ørskov et al., 1980).

The difference in logarithmic nonlinear regression between gas accumulated at different incubation times was due to differences in the chemical components among rangeland plants. By increasing the incubation time to 24 hours, a significant volume of produced gas was obtained, which was the result 
of microbial digestion. Various factors affect the technique of gas production in laboratory conditions. To get accurate results, standard techniques must be applied (Tedeschi et al., 2008).

\section{Conclusion}

Due to the lack of rainfall and fodder to satisfy the nutritional requirements of livestock, understanding of the current capacity and potential for optimal usage in animal nutrition appears essential. According to the outcomes of the chemical composition in this trial, the $\mathrm{CP}$ value of experimented plants was scored between 5.30 to $11.72 \%$, which usually, the level of $7.5 \%$ of $\mathrm{CP}$ is considered as a suitable quality for forage (NRC 2007). The results of CP, ADF, and NDF, as well as the results of in-situ and in-vitro digestibility tests, it could be concluded that the species of Amygdalus lycoides, Atriplex leucoclada, Acer monspessulanum, Artemisia herba-alba, and Amygdalus scoparia have the best chemical compounds and digestibility among plants, respectively.

\section{Disclosure statement}

No potential conflict of interest was reported by the authors.

\section{Animal welfare statement}

The authors confirm that the ethical policies of the journal, as noted on the journal's author guidelines page, have been adhered to and the experimental protocol had been approved by the national ethics committee. The authors confirm that they have followed EU standards for the protection of animals used for scientific purposes.

\section{Funding}

This research did not receive any specific grant from funding agencies in the public, commercial, or not-for-profit sectors.

\section{ORCID}

Ebrahim Talebi, https://orcid.org/0000-0001-6225-2287

\section{References}

Ahmadi, L.; Mirza, M.; Shahmir, F. The volatile constituents of Artemisia marschaliana Sprengel and its secretory elements. Flavour and fragrance journal, 2002, 17(2), 141-143. https://doi.org/10.1002/ffj.1055 
Al-Masri, M. R. Nutritive evaluation of some native range plants and their nutritional and antinutritional components. Journal of Applied Animal Research, 2013, 41(4), 427-431. https://doi.org/10.1080/09712119.2013.792733

Arzani, H.; Zohdi, M.; Fish, E.; Amiri, G. Z.; Nikkhah, A.; Wester, D. Phenological effects on forage quality of five grass species. Rangeland Ecology and Management, 2004, 57(6), 624-629. http://dx.doi.org/10.2111/1551-5028(2004)057[0624:PEOFQO]2.0.CO;2

Askar, A. R.; Gipson, T.A.; Puchala, R.; Tesfai, K.; Detweiler, G. D.; Asmare, A.; Keli, A.; Sahlu, T.; Goetsch, A. L. Effects of stocking rate and physiological state of meat goats grazing grass/forb pastures on forage intake, selection, and digestion, grazing behavior, and performance. Livest. Sci. 2013, 154, 82-92. https://doi.org/10.1016/j.livsci.2013.02.015

Ball, D. M.; Collins, M.; Lacefield, G. D.; Martin, N. P.; Mertens, D. A.; Olson, K. E.; Putnam, D. J.; Undersander; Wolf, M. W. Understanding forage quality. American Farm Bureau Federation Publication,

2001, 1(01). https://pss.uvm.edu/pdpforage/Materials/ForageQuality/Understanding Forage Quality Bal l.pdf

Behnke, R. H.; Scoones, I. Rethinking range ecology: implications for rangeland management in Africa. London: International Institute for Environment and Development. 1992, https://pubs.iied.org/7282IIED

Ben Salem, H.; Nefzaoui, A.; Abdouli, H. Palatability of shrubs and fodder trees measured on sheep and dromedaries. 1. Methodological approach. Anim. Feed Sci. Technol., 1994, 46: 143-153. https://doi.org/10.1016/0377-8401(94)90072-8

Bhattarai, S.; Biswas, D.; Fu, Y. B.; Biligetu, B. Morphological, Physiological, and Genetic Responses to Salt Stress in Alfalfa: A Review. Agronomy, 2020, 10(4), 577. https://doi.org/10.3390/agronomy10040577

Biel, W.; Jaroszewska, A. The nutritional value of leaves of selected berry species. Scientia Agricola, 2017, 74(5), 405-410. https://doi.org/10.1590/1678-992x-2016-0314

Blu, M.; Ørskov, E. R. Comparison of in vitro gas production and nylon bag degradability of roughages in predicting feed intake in cattle. Animal Feed Science and Technology, 1993, 40(2-3), 109-119. https://doi.org/10.1016/0377-8401(93)90150-I

Breshears, D. D.; Knapp, A. K.; Law, D. J.; Smith, M. D.; Twidwell, D.; Wonkka, C. L. Rangeland responses to predicted increases in drought extremity. Rangelands, 2016, 38(4), 191-196. https://doi.org/10.1016/j.rala.2016.06.009

Bumb, I.; Garnier, E.; Bastianelli, D.; Richarte, J.; Bonnal, L.; Kazakou, E. Influence of management regime and harvest date on the forage quality of rangelands plants: the importance of dry matter content. AoB Plants, 2016, 8. https://dx.doi.org/10.1093\%2Faobpla\%2Fplw045

Burger, I. H. Energy needs of companion animals: matching food intakes to requirements throughout the life cycle. The Journal of nutrition, 1994, 124(suppl_12), 2584S-2593S. https://doi.org/10.1093/jn/124.suppl 12.2584s

Colhoun, J. Effects of environmental factors on plant disease. Annual review of phytopathology, 1973, 11(1), 343-364. https://doi.org/10.1146/annurev.py.11.090173.002015

Critchley, C. N. R.; Burke, M. J. W.; Stevens, D. P. Conservation of lowland semi-natural grasslands in the UK: a review of botanical monitoring results from agri-environment schemes. Biological Conservation, 2004, 115(2), 263-278. https://doi.org/10.1016/S0006-3207(03)00146-0 
DiTomaso, J. M.; Monaco, T. A.; James, J. J.; Firn, J. Invasive plant species and novel rangeland systems. In Rangeland Systems 2017 , (pp. 429-465). Springer, Cham. https://doi.org/10.1007/978-3-319-46709-2 13

Dumont, B.; Urra, D. A.; Niderkorn, V.; Lüscher, A.; Porqueddu, C.; Picon-Cochard, C. Effects of climate change on forage quality of grasslands and their use by grazing animals. 2014, 17-p. https://hal.archives-ouvertes.fr/hal-01611403/document

El-Shaer, H. M. Halophytes and salt-tolerant plants as potential forage for ruminants in the Near East region. Small Rumin. Res. 2010, 91, 3-12. https://doi.org/10.1016/j.smallrumres.2010.01.010

Erkovan, H. I.; Gullap, M. K.; Dasci, M.; Ali, K. O. C. Changes in leaf area index, forage quality and above-ground biomass in grazed and ungrazed rangelands of Eastern Anatolia Region. Journal of Agricultural Sciences, 2009, 15(03), 217-223. https://doi.org/10.1501/Tarimbil 0000001094

Ferlemi, A. V.; Lamari, F. N. Berry leaves: An alternative source of bioactive natural products of nutritional and medicinal value. Antioxidants, 2016, 5(2), 17. https://dx.doi.org/10.3390\%2Fantiox5020017

Finch, D. M.; Pendleton, R. L.; Reeves, M. C.; Ott, J. E.; Kilkenny, F. F.; Butler, J. L.; Butler, J.L.; Ott, J.P.; Pinto, J.R.; Ford, P.L.; Runyon, J.B.; Kitchen, S. G. Rangeland drought: Effects, restoration, and adaptation [Chap. 8]. 2016, https://www.fs.fed.us/psw/pubs/50321

Fuhlendorf, S. D.; Engle, D. M.; Elmore, R. D.; Limb, R. F.; Bidwell, T. G. Conservation of pattern and process: developing an alternative paradigm of rangeland management. Rangeland Ecology $\mathcal{E}$ Management, 2012, 65(6), 579-589. https://doi.org/10.2111/REM-D-11-00109.1

Gusmão Filho, J. D.; Fries, D. D.; de Lana Sousa, B. M.; Fagundes, J. L.; Backes, A. A.; Dias, D. L. S.; Pinheiro, S.S.C.; Teixeira, F. A. Growth dynamics and senescence of digit grass as a response to several canopy heights. Revista Mexicana de Ciencias Pecuarias, 2020, 11(1), 38-52. https://doi.org/10.22319/rmcp.v11i1.4913

Hatfield, J. L.; Prueger, J. H. Temperature extremes: Effect on plant growth and development. Weather and climate extremes, 2015, 10, 4-10. https://doi.org/10.1016/j.wace.2015.08.001

Hunt, W. F.; Hay, J. M. A photographic technique for assessing the pasture species performance of grazing animals. In Proceedings of the New Zealand Grassland Association 1990, (pp. 191-195). https://doi.org/10.33584/jnzg.1990.51.1897

Iranian Students' News Agency. https://www.isna.ir/news/97011302554/

Izaurralde, R. C.; Thomson, A. M.; Morgan, J. A.; Fay, P. A.; Polley, H. W.; Hatfield, J. L. Climate impacts on agriculture: implications for forage and rangeland production. Agronomy Journal, 2011, 103(2), 371-381. https://doi.org/10.2134/agronj2010.0304

Keba, H. T.; Madakadze, I. C.; Angassa, A.; Hassen, A. Nutritive value of grasses in semi-arid rangelands of Ethiopia: local experience based herbage preference evaluation versus laboratory analysis. Asian-Australasian Journal of Animal Sciences, 2013, 26(3), 366. https://dx.doi.org/10.5713\%2Fajas.2012.12551

Kfoury, N.; Scott, E. R.; Orians, C. M.; Ahmed, S.; Cash, S. B.; Griffin, T.; Matyas, C.; Stepp, J.R.; Han, W.; Xue, D.; Robbat Jr, A. Plant-Climate Interaction Effects: Changes in the Relative Distribution and Concentration of the Volatile Tea Leaf Metabolome in 2014-2016. Frontiers in plant science, 2019, 10, 1518. https://doi.org/10.3389/fpls.2019.01518

Khalil, J.; Sawaya, W. N.; Hyder, S. Z. Nutrient composition of Atriplex leaves grown in Saudi Arabia. Rangeland Ecology \& Management/Journal of Range Management Archives, 1986, 39(2), 104-107. http://dx.doi.org/10.2307/3899277 
Koutsoukis, C.; Roukos, C.; Demertzis, P. G.; Kandrelis, S.; Akrida-Demertzi, K. The variation of the chemical composition of the main plant species in a subalpine grassland in northwestern Greece. Legume Science, 2019, 1(1), e23. https://doi.org/10.1002/leg3.23

Kulivand, M.; Kafilzadeh, F. Correlation between chemical composition, kinetics of fermentation and methane production of eight pasture grasses. Acta Scientiarum. Animal Sciences, 2015, 37(1), 914. https://doi.org/10.4025/actascianimsci.v37i1.24336

Kumar, S.; Dagar, S. S.; Sirohi, S. K.; Upadhyay, R. C.; Puniya, A. K. Microbial profiles, in vitro gas production and dry matter digestibility based on various ratios of roughage to concentrate. Annals of Microbiology, 2013, 63(2), 541-545. https://doi.org/10.1007/s13213-012-0501-0

Lee, M. A. A global comparison of the nutritive values of forage plants grown in contrasting environments. Journal of plant research, 2018, 131(4), 641-654. https://doi.org/10.1007/s10265018-1024-y

Makkar, H. P. S. Development, standardization and validation of nuclear based technologies for estimating microbial protein supply in ruminant livestock for improving productivity. In Estimation of microbial protein supply in ruminants using urinary purine derivatives, 2004, (pp. 113). Springer, Dordrecht. https://doi.org/10.1007/978-1-4020-2844-1 1

McCollum, D. W.; Tanaka, J. A.; Morgan, J. A.; Mitchell, J. E.; Fox, W. E.; Maczko, K. A.; Hidinger, L.; Duke, C.S.; Kreuter, U. P. Climate change effects on rangelands and rangeland management: affirming the need for monitoring. Ecosystem Health and Sustainability, 2017, 3(3), e01264. https://doi.org/10.1002/ehs2.1264

McDonald, P.; Edwards, R. A.; Greanhalgh, J. F. D.; Morgan, C. A. Animal nutrition, $5^{\text {th }}$ ed., Longman, London, UK., 1996, http://gohardanehco.com/wp-content/uploads/2014/02/AnimalNutrition.pdf

Melesse, A.; Steingass, H.; Boguhn, J.; Schollenberger, M.; Rodehutscord, M. Effects of elevation and season on nutrient composition of leaves and green pods of Moringa stenopetala and Moringa oleifera. Agroforestry systems, 2012, 86(3), 505-518. https://doi.org/10.1007/s10457-0129514-8

Menke, K. H.; Raab, L.; Salewski, A.; Steingass, H.; Fritz, D.; Schneider, W. The estimation of the digestibility and metabolizable energy content of ruminant feedingstuffs from the gas production when they are incubated with rumen liquor in vitro. The Journal of Agricultural Science, 1979, 93(1), 217-222.

Milford, R.; Haydock, K. P. The nutritive value of protein in subtropical pasture species grown in south-eastern Queensland. Australian Journal of Experimental Agriculture, 1965, 5(16), 13-17. https://doi.org/10.1071/EA9650013

Mokhtarpour, A.; Naserian, A. A.; Tahmasbi, A. M.; Valizadeh, R. Effect of feeding pistachio byproducts silage supplemented with polyethylene glycol and urea on Holstein dairy cows performance in early lactation. Livestock Sci. 2012, 148:208-213, https://doi.org/10.1016/j.livsci.2012.06.006

Mountousis, I.; Papanikolaou, K.; Stanogias, G.; Chatzitheodoridis, F.; Roukos, C. Seasonal variation of chemical composition and dry matter digestibility of rangelands in NW Greece. Journal of Central European Agriculture, 2008, 9(3), 547-555. https://jcea.agr.hr/en/issues/article/635

National Research Council. Nutrient requirements of dairy cattle: 2001. National Academies Press. https://books.google.de/books?id=EgWw2Kd9mb4C\&printsec=frontcover\&hl=de, 2001 
Ørskov, E. R.; Hovell, F. D.; Mould, F. T. A. P. The use of the nylon bag technique for the evaluation of feedstuffs. Tropical animal production, 1980, 5(3), 195-213. http://www.fao.org/ag/AGA/AGAP/FRG/tap53/53 1.pdf

Ørskov, E.; McDonald, I. The estimation of protein degradability in the rumen from incubation measurements weighted according to rate of passage. The Journal of Agricultural Science, 1979, 92(2): 499-503, https://doi.org/10.1017/S0021859600063048

Polley, H. W.; Bailey, D. W.; Nowak, R. S.; Stafford-Smith, M. Ecological consequences of climate change on rangelands. In Rangeland Systems 2017, (pp. 229-260). Springer, Cham. https://doi.org/10.1007/978-3-319-46709-2 7

Porto, M. O.; Paulino, M. F.; Valadares Filho, S. D. C.; Detmann, E.; Cavali, J.; Sales, M. F. L.; Valente, É.E.L.; Couto, V. R. M. Nutritional requirements of energy, protein and macrominerals for maintenance and weight gain of young crossbred Nellore $\times$ Holstein bulls on pasture. Revista Brasileira de Zootecnia, 2012, 41(3), 734-745. https://doi.org/10.1590/S1516-35982012000300037

Sampson, A. W. Plant succession in relation to range management (No. 791). US Department of Agriculture. 1919, https://www.nrs.fs.fed.us/pubs/2741

SAS Institute. SAS Users Guide Statistics. Version 9.1 Ed. SAS institute Inc., Cary, Nc. USA. 2007

Sgarbossa, J.; Schmidt, D.; Schwerz, F.; Schwerz, L.; Prochnow, D.; Caron, B. O. Effect of season and irrigation on the chemical composition of Aloysia triphylla essential oil. Revista Ceres, 2019, 66(2), 85-93. https://doi.org/10.1590/0034-737x201966020002

Sommart, K.; Parker, D. S.; Rowlins, P.; Wanapat, M. Fermentation characteristics and microbial protein synthesis in an In vitro system using cassava, rice straw and dried ruzi grass as substrates. Asian-Aud. Journal of Animal science, 2000, 13: 1084- 1093, https://doi.org/10.5713/ajas.2000.1084

Stewart, A. V. Plantain (Plantago lanceolata)-a potential pasture species. In Proceedings of the New Zealand Grassland Association, 1996, (pp. 77-86). https://doi.org/10.33584/jnzg.1996.58.2221

Tedeschi, L. O.; Schofield, P.; Pell, A. N. Determining feed quality for ruminants using in vitro gas production technique. 2. Evaluating different models to assess gas production measurements. In The 4th Workshop of Modeling in Ruminant Nutrition: Application of the Gas Production Technique, Juiz de For a, MG, Brazil, 2008, (p. 15). https://www.nutritionmodels.com/papers/TedeschietalEMBRAPA2008b.pdf

Towhidi, A.; Rostami, F.; Masoumi, R. Chemical composition and in vitro digestibility of nine plant species from Semnan rangeland for camel in Iran. Proceedings of the British Society of Animal Science, 2007, 233-233, https://doi.org/10.1017/S1752756200021360

Van Soest, P. J. Use of Detergents in the Analysis of Fibrous Feeds. I. Preparation of Fiber Residues of Low Nitrogen Content, Journal of Association of Official Analytical Chemists, 1990, 73(4) 1: 487491, https://doi.org/10.1093/jaoac/73.4.487

Vickers, H.; Gillespie, M.; Gravina, A. Assessing the development of rehabilitated grasslands on postmined landforms in north west Queensland, Australia. Agriculture, ecosystems \& environment, 2012, 163, 72-84. https://doi.org/10.1016/j.agee.2012.05.024

Yahdjian, L.; Sala, O. E.; Havstad, K. M. Rangeland ecosystem services: shifting focus from supply to reconciling supply and demand. Frontiers in Ecology and the Environment, 2015, 13(1), 44-51. https://doi.org/10.1890/140156

Zahak meteorological

station statistics.

https://www.wunderground.com/history/daily/ir/zahak/yesterday 
